\title{
The Local Government's Fiscal Risks and Their Solutions under Supply-Side Reform in China
}

\author{
Hu Xinran \\ Business School, \\ University of Shanghai for Science and Technology \\ Shanghai, China
}

\author{
Lei Lianghai \\ Business School, \\ University of Shanghai for Science and Technology \\ Shanghai, China
}

\begin{abstract}
The current five tasks of China's supply-side reform, which are de-capacity, de-stocking, de-leveraging, lower costs and offset weaknesses, will cause new fiscal risks to the local government. We use qualitative analysis to investigate the local government's fiscal risks under the supply-side reform. By analyzing the changes which influenced by the supply-side reform on the local government financial resources, we consider that the gap between local government's fiscal revenue and expenditure will widen. That will lead to three kinds of fiscal risks: local government debt risk, PPP project risk and local fiscal administrative risk. In order to solve these fiscal risks, we suggest the local governments need to improve the local government fiscal risk assessment system, speed up the establishment of local tax sources, reform the storage management mode of PPP project, and regulate the local government administrative departments.
\end{abstract}

Keywords-Supply-side reform; local government; fiscal risk; solution path

\section{INTRODUCTION}

The China's supply-side reform has gradually become a hot topic since 2016. After reviewing the related literatures on China's supply-side reform, we find that many literatures force on discussing what the supply-side reform is, what benefits the supply-side reform can bring to China, and how to implement the supply-side reform. In addition to the three aspects above, some of the literatures have analyzed the risks, including management risks and financial risks, during the process of the supply-side reform from the perspective of enterprises and banks, but there are little literatures analyzing the Chinese government's fiscal risks. In China's current fiscal system, the local governments have a greater probability of fiscal risk events caused by the problems which are the mismatch of financial powers and local administrative management, the low efficiency of the use of fiscal funds, the large scales and low transparency of local government debts. Thus, in the face of China's new socio-economic changes, it is necessary to reexamine the local government's fiscal risks brought by the supply-side reform, and seek the paths to solve these risks.

\section{THE DEFINITION OF LOCAL GOVERNMENT RISKS}

The academic circles in China began to focus on the issue of fiscal risk in 1990s, and the fiscal risk is defined from their research perspectives. Liang Hongmei (1999) [1]considers that the fiscal risk which is caused by the shortcomings of the fiscal system and means and the uncertainties of various economic factors is the possibility of the loss and difficulty of the state in the process of organizing income and arranging expenditure. Yue Shumin (2000) [2] thinks that the fiscal risk is a possibility of fiscal crisis, and the fiscal risk stems from the "financial difficulties" which caused by the sluggishness of fiscal revenue's growth and inflexibility of fiscal expenditure. Liu Shangxi (2003) [3] holds that the government is a dual main body - both an economic main body and a public main body, and different main body bears different risks, so the fiscal risk is a possibility that the economic and social stability and Development is compromised, which are caused by the government-owned public resources are not enough to fulfill their responsibilities and obligations of expenditure. Wu Junpei (2012) [4] has the same opinion with Liu Shangxi, and he considers that the fiscal risk is not just the risk of the fiscal sector, but the various social risks which are reflected in the fiscal aspects.

This paper defines the local government fiscal risk from the government finance itself, and focuses on the risks caused by the changes from the local government fiscal revenue and expenditure during the implementation of the supply-side reform. Thus, the local government fiscal risk is defined as the possibility that the local government cannot perform its function, which caused by the uncertain factors within and outside the local governing system.

\section{AN ANALYSIS OF THE LOCAL GOVERNMENT FISCAL RISKS IN THE CONTEXT OF SUPPLY-SIDE REFORM}

\section{A. The main sources of local government fiscal risks}

"De-capacity, de-stocking, de-leveraging, lower costs and offset weaknesses" are the five tasks of China's supply-side reform since 2016. The implementation of these series of proactive fiscal policies has further exacerbated the contradiction between local government fiscal revenue and expenditure, and the imbalance between local government fiscal revenue and expenditure has become an important source of local government fiscal risk.

The local government fiscal revenue is mainly composed of two parts: the local level fiscal revenue, the central government 
transfer payment. From a structural point of view, in the past 10 years, the local level fiscal revenue accounted for about $60 \%$ of the proportion of the local level fiscal revenue, the remaining the local level fiscal revenue comes from the central government transfer payments. The local level fiscal revenue is contains tax revenue and non-tax revenue. The statistic shows that since 1994 the main the local level fiscal revenue is tax revenue, and the value added tax (VAT) and business tax accounted for the proportion of the sum of the local level fiscal revenue has been more than $30 \%$ in 2016 . With the full implementation of the replacement of business tax with VAT in June 2016, the VAT revenue has become the largest source of the local level fiscal revenue. From the growth rate of local fiscal revenue's point of view, as shown in Figure 1, in the last 10 years, the local level fiscal revenue growth rate shows a downward trend, which in 2016 the local government fiscal revenue growth rate is only $6.18 \%$ which is the slowest growth since China's implementation of the tax reform in 1994. The growth of local government tax revenue has declined significantly, especially in 2016 the growth rate is only $3.24 \%$, which indicating that since 2016 the government's introduction of tax cuts has had a significant impact on the local Government tax revenue, while the local government non-tax revenue growth rates have fluctuated considerably in the past 10 years, but the basic annual growth rate can maintain more than $10 \%$.

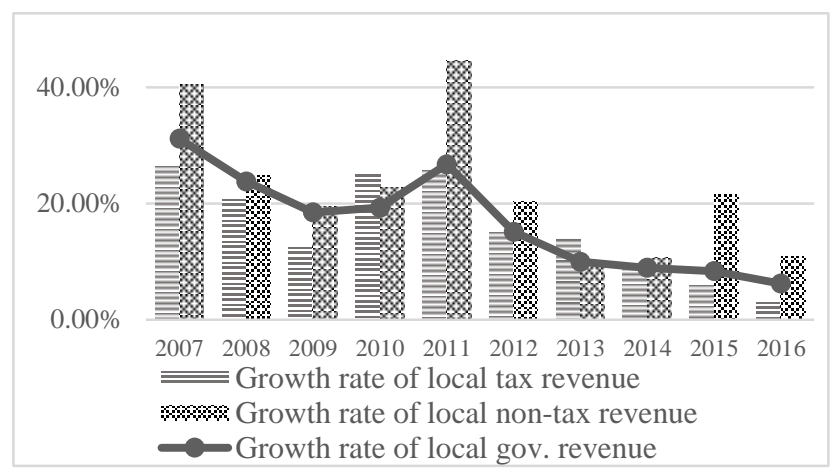

Fig. 1 2007-2016 Local government revenues' growth rate

"Lower costs" is one of the supply-side reform's task, and China's central government have published 6 tax reduction policies, including simplifying the VAT rate structure, reducing the tax rates on agricultural products, tap water, natural gas and other resources, which will affect the VAT revenues that is the largest source of the local level fiscal revenue. According to the existing estimates, more than 380billion-yuan tax burden on all types of market participants will be reduce after the implementation of these tax cuts. At the same time, China's central government has canceled 41 administrative fees, and various local governments do the same. It will also affect the non-tax revenue of local governments. All these policies above will lead the local level fiscal revenue growth rate continue to decline in the short term.

In 2016, education, science and technology, social security and employment, agriculture affairs, health care are the main areas that the local government fiscal expenditure spends on. The figure 3 shows the growth rates of some main areas that the local government fiscal expenditure spends on. The local government fiscal expenditure on education, health care and social security has maintained a high growth rate, but general public service expenditure growth rate has slowed down significantly. The five tasks of supply-side reform will bring new challenges to the local government fiscal expenditure.

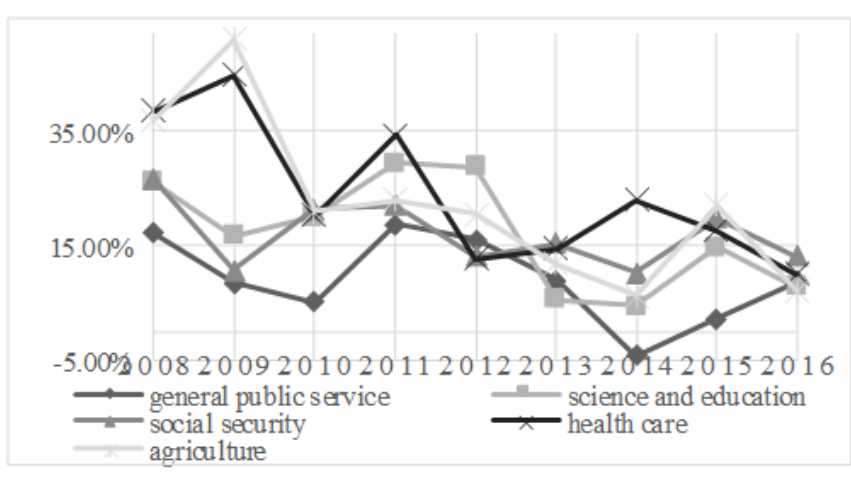

Fig. 2 2008-2016 Local government expenditure growth rate

On one hand, overcapacity has become of the biggest risks of China's real economy, steel, cement, coking coal, chemical fiber, electrolytic aluminum and flat glass are the six hardest hit areas of excess production capacity in China (Liu, 2016) [5]. The enterprises in these areas are mostly labor-intensive, and the government's "de-capacity" policy will lead to cuts, bankruptcy or reorganization of these enterprises, which will inevitably lead to a certain size of unemployment. In order to ensure social stability, local governments should spend more money on social security and employment. On the other hand, there are many weaknesses in China's agriculture industry, manufacturing industry, service industry and social security system (Qi, 2017) [6]. The task of offset weaknesses means the local government need to play a better role in these areas. As local government expenditures on these areas above are rigid, the local governments will face more challenges from shortage of money when to finish the de-capacity and offset weaknesses tasks.

So, the contradictions between local governments' revenue and their expenditure will be further intensified, which will lead to a series of local government risks.

\section{B. The form of local government fiscal risk}

\section{1) Local government debt risk}

The local government debt is a kind of intertemporal allocation of financial funds by local governments who raise money to promote local social and economic development. The public projects where the local government invest often need large scale of money, and have long payback period. Though the local government can solve the problem on lack of money during the construction period through debt financing, local government's fiscal burden is also increased. If the scale of current local government debt is too large, and the project's income is lower than expected, the future cash flow will be inadequate for the repayment of debt, which will seriously affect the future of the local government's cash flow, and the local government debt risk come out. 
Cai Ning (2017) [7] have used the local government budget constraint equation to estimate the scale of local government debt during China's "13th Five-Year plan". The results indicate that the scale of China's local government debt in 2017 will reach 24.66 trillion $\mathrm{RMB}$, and then each year will maintain a growth rate of around $6.5 \%$. Local government debt will reach 29.7 trillion $\mathrm{RMB}$ in 2020. The growing scale of local government debt means that local governments not only need to incur huge amounts of interest each year, but also obtain capital inflows through debt financing, which will continue to accumulate local government debt risk. Through the analysis above, local governments have to face the ever-widening gap between fiscal revenue and expenditure in the background of supply-side reforms. The debt repayment pressure will further increase due to the local government debt continued growing, and that will increase the risk of local government debt.

\section{2) PPP project risk}

Public-Private Partnership (PPP) project is a way to solve local government's financing problem and reducing the risk of local government debt. Ideally, if the PPP model can be successfully implemented, the debt in the local balance sheet can be "drawn out". At the same time, the transparency of government debt and financial efficiency can be improved through the introduction of social capita. But the current situation shows that the PPP project contains a lot of project risk, and these risk will be transformed into fiscal risk gradually.

First, some of projects in the government's PPP project date base are not suitable for the PPP model. According to a research conducted by Asian Development Bank, the social capital will join the PPP project when the IRR exceeds to $7 \% \sim 8 \%$. But the long-term borrowing interest rate in Chinese bank is $4.9 \%$, and the government bonds' interest rate is around 4\%. The local government's cost on PPP project is higher than debt financing. If the PPP project is promoted by force, the local government's financial burden will be increased, which induced the local government fiscal risk.

Second, the PPP project financing may lead to local government debt implicit and hide the local government debt risk. At present, China has implemented cap management of local government debt, but local governments can use the existing government debt statistics model to reduce the government debt by designing a specific PPP project, and achieve the purpose of breaking the local government debt cap. Some private sectors have signed an equity repurchase agreement with local government to require the government to repurchase shares held by the private sector for a period of time after the project is put into operation. This method leads the government and the private sector fail to burden long-term risks together, and once the private sector withdraws from the PPP project, the local government will burden the entire project's operational risk.

Third, the local government and the private sector tend to different interests in the PPP project: the local government tends to provide public goods or services, while the private sector is more concerned about whether the project is profitable. That will lead to the risk that the private sector encroaches on public sector interests by PPP project. In some cases, the local government attracts private sector participation through various kinds of irrational guarantees or promises, excessive subsidies, which will inevitably lead to a heavier financial burden of local government.

\section{3) Local fiscal administrative risks}

The local fiscal administrative risks are mainly manifested in the following two aspects in the context of supply-side reform. First, the local financial departments don't obey the budget law and government information disclosure regulations to open local government fiscal data, which causing information asymmetry on local government finance. That will lead to the misjudged of local government fiscal health. Second, due to the increasing gap between local government revenue and expenditure, there may exist a violation of the budget law in order to make up for the lack of financial capital demand. The illegal acts will affect the local government's credit, which is not conducive to the issuing of local government bonds.

\section{THE PATH OF SOLVING LOCAL GOVERNMENT FISCAL RISKS IN CONTEXT OF SUPPLY-SIDE REFORM}

Although the supply-side reform has brought many fiscal risks to the local government, the reform has also created certain chance to resolve the problems. The local governments should seize the historical opportunity and solve these risks from the following aspects.

First, the local government should improve the local government fiscal risk assessment system. The local government's deficit rate and the government debt ratio should be estimated scientifically and rationally. The local government's budget deficit rate and the upper limit of debt ratio should be delineated and be enforced strictly. The Chinese local governments often use the security lines quoted from Treaty of Maastricht, but these lines may not suitable for Chinese local governments. The fiscal condition in some place is better than others, so the local government can bear a higher deficit rate and debt ratio. But, in rural areas in China, even a relative low deficit rate can cause local government fiscal risk. By building a scientific and rational local government fiscal risk assessment system, the local government debt risk can reduce a lot.

Second, the local tax sources should be established so as to increase the local level fiscal revenue. The mismatch of local financial powers and local administrative management forces local government to raise money from local government financing platforms and land finance, which is an important source local government fiscal risk. It is necessary to re-divide the shares of taxation between the central government and local governments in accord with the local government's fiscal expenditure responsibilities, and solve the mismatch problems from supply side.

Third, the storage management mode of PPP project should be reformed. The PPP project catalogue should be divided into three sub catalogs according to the different IRR. The three sub catalogs are marketing projects which have a relative high IRR that can attract private investment without government subsidy, semi marketing projects which have low IRR and need 
government subsidy, and public projects which are not profitable and only the government will conduct.

Last, the local government administrative departments' behavior should be regulated, and the role boundaries of local governments in the supply side reform should be delineated. The main purpose of the supply-side reform is to respect the market law, optimize the allocation of resources by the market, and achieve the goal of optimizing the supply structure. The central government has carried out a top-level design for the supply-side reforms, and local governments should make clear their own play, follow the central government policies and regulations, abide by the boundary of the role, do not offside, no vacancy, dislocation in the local financial management. Only in this way can reduce the local fiscal administrative risks.

\section{CONCLUSIONS}

Because the local fiscal risk is long-term, complexity, concealment, the relevant fiscal data of local government is difficult to obtain. The qualitative analysis is use to investigate the local government's fiscal risks under China's supply-side reform. By analyzing the changes which are influenced by the supply-side reform on the local government financial resources, we consider that the local government revenue's growth rate will continue to decline in the short term, and the local government expenditure will expand quickly. Thus, the gap between local government's fiscal revenue and expenditure will widen. The contradiction between revenue and expenditure will lead to local government debt risk, PPP project risk and local fiscal administrative risk. In order to solve these fiscal risks, we suggest the local governments need to improve the local government fiscal risk assessment system, speed up the establishment of local tax sources, reform the storage management mode of PPP project, and regulate the local government administrative departments.

\section{REFERENCES}

[1] H.M. Liang, "Financial risk in transition period and its prevention and control", Public Finance Research, vol. 3, pp. 38-39, 1999.(In Chinese)

[2] S.M. Yue, "Financial difficulties and financial risks ", Contemporary Economic Research, vol. 1, pp. 63-67, 2000. (in Chinese)

[3] S.X. Liu. "Framework on China's Fiscal Risk", Economic Research Journal, vol. 5, pp. 23-31, 2003.(in Chinese)

[4] J.P. Wu, B. Zhang, "Financial risk in the construction of China's market economic system", Finance \& Trade Economics, vol. 1, pp. 10-16, 2012. (in Chinese)

[5] C.A. Liu, "Potential risks and solutions of supply-side reform", Modern Economic Research, vol. 12, pp. 20-24, 2016. (in Chinese)

[6] M.M. Qi, "The deepening of supply side reform: the key points and main measures to offset weaknesses - $2016 \sim 2017$ China economic annual conference review four", Review of Economic Research, vol.10, pp. 79-82, 2017. (in Chinese)

[7] N. Cai, Y. Liu, "Prediction of provincial local government debt scale in China -- Based on the framework of full bore financial revenue and expenditure", Finance Forum, vol. 2, pp. 25-34+45, 2017. (in Chinese) 